\title{
Pogled u toponimiju Kotorskoga zaljeva ${ }^{1}$
}

\author{
Domagoj Vidović \\ Institut za hrvatski jezik i jezikoslovlje, Zagreb \\ dvidovic@ihjj.hr
}

SAŽETAK: U ovome se radu obrađuje petstotinjak toponima u Kotorskome zaljevu. U uvodnome se dijelu članka iznose temeljni povijesni i demografski podatci. U središnjemu se dijelu mjesni toponimi razvrstavaju prema motivaciji i s obzirom na jezično postanje. Motivacijski se toponimija Kotorskoga zaljeva izdvaja po iznadprosječnomu udjelu toponima antroponimskoga postanja te toponima uvjetovanih titularima crkava, među kojima se izdvaja toponim Sutorman (sanctus Romanus), prežitak rane romansko-slavenske simbioze.

Ključne riječi: toponimi; demografija; Kotor; Romani; Slaveni; Hrvati

\section{Uvod}

Bokeljska je toponimija izazvala zanimanje mnogih onomastičara. Pojedinačni su toponimi obrađeni u radovima Petra Skoka (bavio se uglavnom ojkonimima, predrimskim toponimima i toponimima romanskoga postanja; Skok 1950. i ERHSJ IIII), Petra Šimunovića (uglavnom je obrađivao hagionime; Šimunović 1984-1985., 1996), Gracijele Čulić (analizirala je povijesne toponime; Čulić 1999-2001., 2002) i

1 Rad je izrađen na istraživačkome projektu Istraživanje antroponimije na tlu Hrvatske u XV. stoljeću-CroNomaXV (IP-2018-01-6053), koji u cijelosti financira Hrvatska zaklada za znanost i koji se provodi u ustanovi nositelju projekta Institutu za hrvatski jezik i jezikoslovlje. Ovom prigodom zahvaljujem predsjedniku Hrvatskoga nacionalnog vijeća Crne Gore Zvonimiru Dekoviću na svesrdnoj organizacijskoj potpori i mnogim kulturološkim, povijesnim i jezičnim podatcima tijekom arhivsko-terenskoga istraživanja provedenoga od 15. do 24. studenoga 2018. u Boki kotorskoj i Baru te na dostupnosti i nakon povratka u Hrvatsku. Ujedno zahvaljujem mojim susretljivim sugovornicima i domaćinima Gracijeli Čulić (na usmenome upućivanju u razvoj i posebnosti bokeljske antroponimije, pravoj maloj školi bokeljske onomastike), Slavku Dabinoviću (na upućivanju u antroponomastičke i toponomastičke radove objavljene u Godišnjaku Pomorskoga muzeja u Kotoru), Dijani Milošević (na strpljivosti i dostupnosti tijekom i nakon istraživanja) u Kotoru i Ani Vuksanović (na organizacijskoj pomoći u održavanju predavanja za učenike i građanstvo u Donjoj Lastvi) u Tivtu. Zvonimiru Dekoviću, Dijani Milošević i Ani Vukasanović ujedno zahvaljujem na dodatnim provjerama jezičnih podataka. Također zahvaljujem Maji Katušić i Marinku Tomasoviću na pomoći u pripremi istraživanja te načelnici Arhivskoga odsjeka - Istorijskoga arhiva u Kotoru Snežani Pejović na iznimnoj susretljivosti. 
Dunje Brozović Rončević (obradila je dio hidronima; Brozović Rončević 1997., 1999), a suvremena toponimija u radovima Cjelimira Stanića (obradio je toponimiju Mula, Prčanja i Škaljara; Stanić 1978. i 1979-1980) i Antuna Tomića (obradio je toponimiju Dobrote; Tomić 1977. i 2010). Upravo su radovi Cjelimira Stanića i Antuna Tomića, u kojima su popisani terenski prikupljeni toponimi, u kojima se za znatan dio toponima donosi opis referenta, a pojedinima se nastoji utvrditi etiologija i etimologija, bili glavnim vrelom toponomijske građe za ovaj rad. Kako cjelovita toponomastička razredba u tim radovima nije provedena i kako je zbog obilnih migracija starosjedilačkoga stanovništva iz navedenih naselja teško očekivati da bi se novim terenskim istraživanjem znatnije dopunila građa, obradbom se zapisanih toponima i manjim dopunama utemeljenim na arhivskome $\mathrm{i}$ terenskome istraživanju provedenom $\mathrm{u}$ Boki kotorskoj od 15. do 24. studenoga 2018. nastoji stvoriti potpunija slika kotorske i općenito bokeljske toponimije te se razlučiti različiti jezični slojevi, koji se iz nje razaznaju. Ovim su radom obuhvaćeni toponimi središnjega, istočnoga i južnoga dijela Kotorskoga zaljeva unutar područja kojemu pripadaju naselja Dobrota, Kotor, Škaljari, Muo, Prčanj i Stoliv.

\section{Kratak povijesni pregled}

Budući da je burna kotorska i bokeljska povijest bogato dokumentirana, iznijet ću tek neke osnovne podatke. Na području Kotora u III. je stoljeću postojalo grčko naselje, koje su u V. stoljeću porušili Goti. Nakon propasti Zapadnoga Rimskoga Carstva grad je potpao pod bizantsku vlast. Kotorska je, a time i bokeljska povijest obilježena činom Andrije Saracena (Andreaci Saracenis), koji je 809. prenio moći svetoga Tripuna iz Carigrada u Kotor. Do 1185. nad Kotorom se smjenjivalo bizantsko i dukljansko vrhovništvo, 1186-1371. Kotor je bio pod vrhovništvom Nemanjića, 13711384. hrvatsko-ugarskih, a 1384-1391. bosanskih vladara. Veći dio srednjega i kasnoga srednjovjekovlja Kotor je bio autonomnom komunom s knezom i trima vijećima, a potpunu je samostalnost uživao 1391-1420. Godine 1420. grad se predao Mletačkoj Republici pod čijom je upravom, kao glavni grad Mletačke Albanije i sjedište izvanrednoga providura, ostao do njezine propasti 1797. Osmanlijskim upadima i opsadama unatoč Kotorski zaljev, uz iznimku Glogovca i Orahovca, nikad nije bio pod osmanlijskom vlašću za razliku Grblja (područja između poluotoka Luštice i Budve smještenoga jugoistočno od Kotora), koji je pod Osmanlijama ostao 1497-1715., i zapadnoga dijela Boke kotorske (uz iznimku Đurića, Kostanjice, Lipaca i Strpa, kao mletačkih enklava), koji je, iz kraće prekide, bio pod osmanlijskom vlašću 1482-1687. Osmanlijski su upadi ipak posredno utjecali na promjenu vjerskoga i narodnosnoga sastava mjesnoga stanovništva jer su Mlečani koncem XVII. stoljeća naselili nekoliko tisuća istočnohercegovačkih pravoslavaca u zapadni dio Boke kotorske. Dvije su austrijske uprave (1797-1918) bile kratkotrajno isprekidane ruskom (1806 -07), francu- 
skom (1807-13) i crnogorskom (1814) vlašću. Tijekom njih su se u Boku kotorsku u znatnoj mjeri doseljavali i stanovnici različitih dijelova Habsburške Monarhije. Godine 1918. Kotor je ušao u sastav Kraljevine Srba, Hrvata i Slovenaca, a 1929-41. u sastav Zetske banovine. Tijekom Drugoga svjetskog rata Boka kotorska bila je izravno pripojena Italiji 1941- 43., pa pod izravnom njemačkom upravom. Uspostavom Federativne Narodne Republike Jugoslavije Boka kotorska ušla je u sastav Crne Gore. Nakon raspada Jugoslavije bila je u sastavu Savezne Republike Jugoslavije (1992-2003) te Srbije i Crne Gore (2003-06), a od 3. lipnja 2006. Boka kotorska nalazi se u sastavu samostalne Crne Gore.

\section{Osvrt na promjene vjersko-narodnosnoga sastava Boke kotorske}

Doseljavanjem Slavena u Boku kotorsku otpočelo je gotovo tisućstoljetno razdoblje romansko-slavenske simbioze. U njezinu se početnome dijelu, tijekom kojega je dalmatski jezik bio materinskim jezikom mjesnoga romanskoga i poromanjenoga stanovništva, ta simbioza ponajvećma odrazila u toponimiji, poglavito u hagionimima, ne samo u Boki kotorskoj nego i istočnije, primjerice: Sušćepan »sveti Stjepan «- starije ime Herceg-Novoga, a danas ojkonim sjeverno od Igala te povijesno ime negdašnjega otoka, a danas poluotoka Sveti Stefan kod Budve, Sutorina »sveta Marija« naselje kod Herceg-Novoga, Sutomore »sveta Marija« - ojkonim kod Bara, Sutomoršcica »sveta Marija« - ojkonim u Crmnici, Sutulija »sveti Ilija« - brdo kod sela Zagora u Grblju (možda i Stoliv), Sutvara »sveta Barbara« - naselje kod Kotora, Stivan »sveti Ivan« - hodonim u Budvi, Stivančica »sveti Ivan« - obalni toponim u Spiču, Sustaš»sveti Anastazije« - ojkonim kod Bara, Suban »sveti Urban«, Sutorman »sveti Roman« - brdo između Bara i Crmnice, Velja i Mala suta < suta »sveta« - toponimi u Zupcima kod Bara, Velja i Mala Vrsuta < suta »sveta« - gora iznad Sutomora i Sućekla »sveta Tekla« - predio u Sutomoru (za barski dio usporediti Marković 2006: 21). Do konca srednjovjekovlja, kad je slavensko prevladalo i u samome Kotoru, stanovništvo je samoga grada i uže okolice bez obzira na jezično podrijetlo bilo isključivo katoličko s iznimkom Grblja. Zbog zbjega su Grbljana tijekom Kandijskoga rata godine 1657. mletačke vlasti dopustile uporabu crkve svetoga Luke u Kotoru (izgrađene 1195) za pravoslavne vjernike te se postupno počeo povećavati udio pravoslavaca u zaljevu. Njihov se udio znatnije povećao nakon oslobađanja Herceg-Novoga i Risna koncem XVII. stoljeća od osmanlijske vlasti². Tijekom austrijske se uprave u Boku kotorsku doselio i velik udio stranaca, pa je, primjerice, udio stanovništva kojemu je materinski jezik bio njemački 1890. u Kotoru iznosio 9,6\%. Ipak, Hrvati su sve do konca austrijske vladavine ostali većinsko stanovništvo Kotorskoga

2 Primjerice, prva se pravoslavna obitelj u kotorsko prigradsko naselje Škaljari doselila tek 1760., a udio je pravoslavaca u Kotoru 1774. iznosio 15,85\%. 
zaljeva i Boke kotorske općenito, a romansko-slavenska (ponajprije mletačko-hrvatska) jezična simbioza ogledala se u najvećoj mjeri u upravnome, kulturnome i graditeljskome leksiku, koji se odrazio i u mjesnoj toponimiji. ${ }^{3}$

Tablica 1. Broj stanovnika po naseljima 1921-2011.

\begin{tabular}{|l|c|c|c|c|c|}
\hline Naselje & $\mathbf{1 9 2 1}$ & $\mathbf{1 9 8 1}$ & $\mathbf{1 9 9 1}$ & $\mathbf{2 0 0 3}$ & $\mathbf{2 0 1 1 .}$ \\
\hline Dobrota & 1182 & 5435 & 7283 & 8169 & 8189 \\
\hline Kotor & 4801 & 5345 & 5620 & 1331 & 961 \\
\hline Muo & 584 & 722 & 740 & 677 & 619 \\
\hline Prčanj & 585 & 1211 & 1213 & 1224 & 1130 \\
\hline Stoliv & 291 & 374 & 349 & 346 & 348 \\
\hline Škaljari & - & - & - & 4002 & 3807 \\
\hline Ukupno & $\mathbf{7 4 4 3}$ & $\mathbf{1 3 8 0 7}$ & $\mathbf{1 5 2 0 5}$ & $\mathbf{1 5 7 4 9}$ & $\mathbf{1 5 0 5 4}$ \\
\hline
\end{tabular}

Demografski se sastav Boke kotorske počeo znatnije mijenjati njezinim ulaskom u sastav Kraljevine Jugoslavije, a najveće su se promjene dogodile tijekom i nakon Drugoga svjetskoga rata kad se u međupopisnome razdoblju 1931-48. u Boki kotorskoj, po procjeni Crkvenčića i Schallera (2007: 76, 77), broj Hrvata, zbog stradanja u Drugome svjetskom ratu, iseljavanja i prikrivanja narodnosnoga podrijetla, smanjio za 7000 , odnosno s oko 13000 na 5860, a udio smanjio s oko $42 \%$ na $28,7 \%$. Pritom treba napomenuti kako se u navedenim naseljima broj Hrvata 1921-2011. smanjio za gotovo četiri puta, a u postotnome udjelu za 6,5 puta (usp. tablicu 2.). Na razmjere promjena u narodnosnome sastavu stanovništva nakon Drugoga svjetskog rata ukazuje i podatak da se u kotorskoj općini udio Hrvata s 20,93\% 1961. smanjio na 6,87\% prema rezultatima popisa iz 2011. te da se i broj i udio Hrvata smanjivao u svakome međupopisnom razdoblju osim 1991-2003. Da je prikrivanje narodnosnoga podrijetla iz različitih pobuda u velikoj mjeri i dalje znatno prisutno, pokazuje podatak da udio katolika u kotorskoj općini iznosi $11,76 \%$, odnosno da je za više od $40 \%$ veći od udjela Hrvata. Među katolicima je koji se nisu izjasnili kao Hrvati velika većina onih hrvatskih korijena.

3 Pritom treba imati na umu kako u Boki kotorskoj u preporodnome razdoblju nadijevanje romanskih imena te uporaba talijanskoga jezika nisu imala političke konotacije kao u ostatku Dalmacije i Istri jer se time naglašavala razlika u odnosu na pravoslavno stanovništvo. Hrvatsko je stanovništvo prilagodilo romansko obalno te (kao katoličko) crkveno i kulturno nazivlje te ga uklopilo u vlastiti imenski sustav (i antroponimijski i toponimijski) te je prema njemu bilo znatnije otvoreno od pravoslavnih stanovnika Boke kotorske. 
Tablica 2. Broj i udio Hrvata po rezultatima službenih popisa stanovništva

\begin{tabular}{|l|c|c|c|c|c|}
\hline $\begin{array}{l}\text { Hrvati po } \\
\text { naseljima }\end{array}$ & $\mathbf{1 9 2 1}$ & $\mathbf{1 9 8 1}$ & $\mathbf{1 9 9 1}$ & $\mathbf{2 0 0 3 .}$ & $\mathbf{2 0 1 1 .}$ \\
\hline Dobrota & 689 & 424 & 459 & 535 & 476 \\
& $(58,29 \%)$ & $(7,80 \%)$ & $(6,30 \%)$ & $(6,55 \%)$ & $(5,81 \%)$ \\
\hline Kotor & 2617 & 515 & 505 & 116 & 113 \\
& $(54,51 \%)$ & $(9,64 \%)$ & $(8,99 \%)$ & $(8,72 \%)$ & $(11,76 \%)$ \\
\hline Muo & 420 & 137 & 128 & 137 & 115 \\
& $(71,92 \%)$ & $(18,98 \%)$ & $(17,30 \%)$ & $(20,24 \%)$ & $(18,58 \%)$ \\
\hline Prčanj & 483 & 193 & 189 & 186 & 170 \\
\hline Stoliv 5 & $(82,56 \%)$ & $(15,94 \%)$ & $(15,58 \%)$ & $(15,20 \%)$ & $(15,04 \%)$ \\
& 210 & 81 & 45 & 54 & 58 \\
\hline Škaljari & $(72,16 \%)$ & $(21,66 \%)$ & $(12,89 \%)$ & $(15,61 \%)$ & $(16,67 \%)$ \\
& - & - & - & 489 & 415 \\
\hline Ukupno & & & & $(12,22 \%)$ & $(10,90 \%)$ \\
& $\mathbf{4 4 1 9}$ & $\mathbf{1 3 5 0}$ & $\mathbf{1 3 2 6}$ & $\mathbf{1 5 1 7}$ & $\mathbf{1 3 4 7}$ \\
& $\mathbf{( 5 9 , 3 7 \% )}$ & $\mathbf{( 9 , 7 8 \% )}$ & $\mathbf{( 8 , 7 2 \% )}$ & $\mathbf{( 9 , 6 3 \% )}$ & $\mathbf{( 8 , 9 5 \% )}$ \\
\hline
\end{tabular}

Iako je Kotorski arhiv iznimno bogat povijesnom toponomastičkom građom, iseljavanjem Hrvata kao starosjedilaca padaju u zaborav mnogi toponimi, pa Cjelimiru Staniću i Antunu Tomiću dugujemo zahvalnost što su ih zabilježili.

\section{Mjesni toponimi}

\subsection{Ojkonimi}

\subsubsection{Dobrota}

U povijesnim se vrelima naselje spominje 1260. Ojkonim je antroponimskoga postanja $(<$ Dobrota $<$ *Dobrot'a (vas) $<$ Dobrota $<$ Dobre/Dobro $<$ Dobromir/Dobroslav). U starijim se razdobljima Dobrota dijelila na četiri područja (Tomić 1977:137) od istoka prema zapadu: Vrtline (nekoć Vrtovi; od Škurde do Plagenata; ondje su se nalazili vinogradi kotorskih patricija), Ilijaševići (od Plagenata do crkve svetoga Matije), Do-

4 Prema rezultatima popisa stanovništva iz 2011. u Dobroti je živjelo 948 (11,58\%), u Kotoru 197 (20,51\%), Mulu 150 (24,23\%), Prčanju 238 (21,06\%), Stolivu 103 (29,60\%), a u Škaljarima 664 (17,44\%) katolika. Ukupno je, dakle, u navedenim naseljima živjelo $2300(15,28 \%)$ katolika, gotovo dvostruko više nego Hrvata.

5 U službenim se popisima od 1948. navode naselja Donji i Gornji Stoliv, no u ovome su članku podatci izneseni skupno. 
brota (od crkve svetoga Matije do Raškov-brijega) i Ljuta (od Raškov-brijega do rijeke Ljute). Kao pomorsko-trgovačko središte naselje je doživjelo procvat XVII. i XVIII. stoljeću (opširnije u Tomić 2010 i Babić 2019: 38-39), a danas je najnapučenije naselje kotorske općine.

\subsubsection{Kotor}

Budući da tumačenje ojkonima Kotor nadilazi opseg ovoga članka, navodim kako je opširniju raščlambu ojkonima s povijesnim potvrdama iznio Čače (1998: 29-32) prenoseći Mayerovo mišljenje kako se ojkonim može povezati s korijenom *qat- te ustvrdivši da se semantičkim pomacima značenje toga korijena pomaklo od temeljnoga značenja »plot« i »ograđeno mjesto« do izvedenoga »utvrda«. Petar Skok (1927: 73) navodi kako se grčko kátera poistovjetilo s latinskim catena navodeći usporednicu u toponimu Catene za današnje Verige u Bokokotorskome zaljevu. Slavensko je ime Kotorъ potvrđeno od XIII. stoljeća. Kotor je osim upravnoga i vjersko katoličko središte Boke kotorske s katedralom, tridesetak crkava i šest samostana. Tijelo blažene Ozane Kotorske (1493-1565) položeno je u crkvi svete Marije.

\subsubsection{Muo}

Petar Skok (ERHSJ II: 480) ojkonim drži dalmatskim prežitkom izvodeći ga od lat. moles. Apelativ muo označuje pristanište. Slavenski je lik ojkonima zapisan u XV. stoljeću, a da je naselje znatno starije, potvrđuje podatak o posveti crkve svetoga Kuzme i Damjana te svete Elizabete iz 1262. Iz naselja potječe blaženi Gracija (1438-1508), čije se moći čuvaju u župnoj crkvi Blažene Djevice Marije Pomoćnice Kršćana.

\subsubsection{Prčanj}

Ojkonim Petar Skok (ERHSJ III: 29) izvodi od rimskih rodovskih imena Ponius ili Porcius. Godine 1326. potvrđeni su likovi Perçana i Parsiana, a 1331. Parçan(ri)a. O starosti naselja svjedoči i crkva svetoga Tome iz IX. stoljeća. Pučkom se etimologijom ojkonim katkad povezuje s apelativom prč »(raspolodni) jarac«. Tijekom XVIII. stoljeća Prčanj se prometnuo u kulturno središte s bogatom knjižnicom franjevačkoga samostana svetoga Nikole.

\subsubsection{Stoliv}

Ojkonim se prvi put spominje 1326. (vinea de Stativo). Petar Skok (ERHSJ II: 337, 338) smatra ga dalmatskim prežitkom. Putanec (1963: 146) i Šimunović (1984-1985: 163) drže da je riječ o hagionimu tvorenom od dalmatskoga pridjeva san(c)tu(s) 
(< sanctus Elias »sveti Ilija«). Najviši se vrh Vrmca naziva Sveti Ilija (visok 785 metara), a u Stolivu je 1556. proširena već izgrađena crkva svetoga Ilije. Po pučkoj je etimologiji naselje prozvano Stolivom jer je svaki mladić trebao zasaditi sto maslina (sto oliva) kako bi se mogao oženiti.

\subsection{6. Škaljari}

Naselje je u srednjovjekovlju nosilo ime Surana uščuvano u današnjemu obalnom toponimu Šuranj. Taj je povijesni toponim vjerojatno motiviran pridjevkom ili prezimenom kotorske vlasteoske obitelji Surana/Syrana (nastavak *-j upućuje na negdašnje posjedničke odnose). Novije je ime - Škaljari - također antoponimijskoga postanja, zapisano od 1451. te se dovodi u vezu s apelativom škalja »sitni tucani« (usp. tal. scaglia; ERHSJ III: 398). Stanovnici su se Škaljara, naime, uz zemljoradnju i stočarstvo, uvelike bavili građevinarstvom. Etnik Škaljarin odrazio se u hrvatskome bokeljskom prezimenskom fondu.

\subsection{Motivacijska razredba toponima}

$\mathrm{U}$ ovome se odlomku toponimi dijele po motivaciji. Uz toponim donosim osnovni podatak, a u bilješkama pod osnovnim tekstom dodatna objašnjenja. Uz toponime navodim i kratice naselja na čijemu su području zabilježeni:

$\mathrm{D}=$ Dobrota

$\mathrm{K}=$ Kotor

$\mathrm{M}=$ Muo

$\mathrm{P}=$ Prčanj

$\mathrm{S}=$ Stoliv

$\check{S}=\check{S} k$ aljari

\subsubsection{Toponimi motivirani geomorfološkim odlikama zemljopisnoga objekta}

\subsubsection{Zemljopisni nazivi u toponimiji (toponimijski apelativi i izvedenice)}

4.2.1.1.1. Odrazi toponimijskih naziva: ${ }^{6}$ Boljun $\left(<\right.$ boljun $^{7} »$ vrelo«; S), Brda (D), Bregovi (̌̌), Brijeg (P), Do (P), Glavica (D), Grebene (Š), Gurdić (usp. gurgite < gur-

6 U ovu su skupinu pridodani i neki odnosni toponimi (npr. Mala rijeka, Među ponte, Velja peča) u kojima su se odrazili toponimijski nazivi, koji se nisu odrazili u jednorječnim toponimima.

7 Apelativ boljun »vrelo« uščuvan je u obližnjim Lepetanima (Brozović Rončević 1997: 29). Istoimeni vrh u Vrmcu visok je 447 metara. 
ges $^{8}$; ERHSJ I: 598; K), Fama (P), faža (<jaža9 »vodojaža, odvodni kanal«; Š), fezera (Š), Kalozi (D), Kaluža (Š), Koritca (D), Kuk (P), Ledine (D, P), Lokanj ${ }^{10}$ (< lokanj

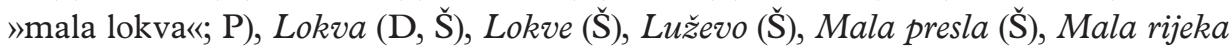
(M, P), Među ponte (< ponta »rt«< mlet. ponta; P), Močali (: močiti; Š), Mramor (*mer- »glodati, gristi«; Bezlaj 2003: 351, 1023; Š) Nakraj kose (P), Peć (<peć »pećina«; D), Pestingrad (< *Peštinjgrad < peštı »pećina«; usp. ERHSJ II: 629; D), Poljana

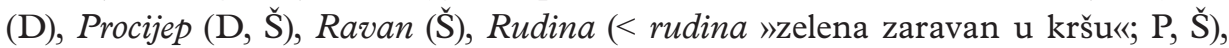
Skok (< skok »plitak potok«; D), Spenik (usp. *Spionik ${ }^{11}<$ spila/špila »spilja, pećina«; Š), Spile ( $\left.\mathrm{P}^{12}, \check{S}^{13}\right)$, Strana (Š), Tinjak (< tinja ${ }^{14} »$ blato«; D), Točilo (točilo »mjesto ljevkasta oblika nastalo spiranjem vode na strmim padinama«; D, M), Ublić (<ubo $o^{15}$

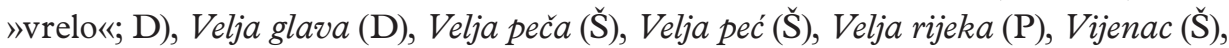
Zjalovo (usp. zjalo »otvor«; P), Zvjerovnik ${ }^{16}($ Š).

U mjesnoj su se toponimiji odrazili mnogi hidronimski apelativi: oni koji se odnose na blatišta (kaloz ${ }^{17}$ i kaluža »kaljuža«, luža i močao ${ }^{18}$ »mokrina« te tinja »blato«), vrelišta (boljun, ubo »ubao«, vrelo ${ }^{19} \mathrm{i} z v i r »$ vrelo«), zbirališta vode (jezero, lokanj ${ }^{20}$ »mala lokva« i lokva) te stalne (jaža, potok i rijeka $a^{21}$ ) i povremene vodotokove (korito, *mer-, skok i točilo). Odrazom su geomorfologije krša apelativi jama, ledina, peča »ko-

8 U krčkoj povijesnoj toponimiji srodni su se apelativi (usp. toponim Gorak) toponimizirali i označuju dolinicu, vrtaču (ERHSJ I: 598).

$9 \mathcal{J} a \check{a} a$ se nalazi na potoku Zvjerovniku.

10 Riječ je o pojilištu stoke iznad stare župne crkve u Prčanju.

11 Spenik je vrelo kod stare župne crkve Gospe od Snijega u Škaljarima. Usp. hidronim Špijenik na Stjepan-Krstu kod Stoca (Vidović 2014a: 142).

12 U Prčanju su Spile predio zapadno od Velje rijeke te uz put od Markov-rta do Gornje Lastve.

13 Riječ je o dvama predjelima, jednim ispod Čiste strane i jednim ispod Vrmca.

14 Tinjak je predio iznad vrela Kavalin. Za odraze osnove *tinja usp. Brozović 1999: 35. Apelativ nije proziran mjesnomu stanovništvu.

$15 \mathrm{U}$ istočnoj Hercegovini apelativ $u b o$ češće označuje zdenac.

16 Riječ je o potoku koji se spušta s Lovćena u more. Mjesni je toponimski lik hiperijekavski.

17 Kalozi su toponim nastao od hibridnoga hrvatsko-romanskoga apelativa $(<k a l+o z$ [usp. lat. -osus]).

18 Na mogući apelativ *močao (usp. kao, ubo) upućuje hidronim Močao u Baošićima kod Herceg-Novoga.

19 Apelativ je u toponimiji uščuvan kao dio dvorječnoga hidronima Vrelo Gurdić. Mjesno je u uporabi apelativ vreo. Obrađena građa potvrđuje tezu kako na hrvatskome povijesnom prostoru nema starijih odraza apelativa $i z v o r$, ali su u Boki kotorskoj, kao na otocima i u priobalju, zabilježeni odrazi dijalektnoga lika zvir (usp. Brozović Rončević 1997: 5 i bokeljski hidronim Zvjerovnik).

20 Mjesno je potvrđen i apelativ batun »mala lokva za pojenje stoke«.

${ }_{21}$ Na obrađenome su području Mala i Velja rijeka povremeni vodotoci, a njihovo se ime prenijelo i na obližnje uvale u koje se slijevaju. 
mad zemlje«, peć »pećina«, poljana, ravan, rudina »zaravan«, spila i zjalo »otvor, bezdan«, a u mjesnoj je toponimiji uščuvan i obalni apelativ ponta ${ }^{22} » r \mathrm{r} \ll$. Na oronimske apelative upućuju toponimi Brdo, Brijeg, Glavica, Greben, Kosa, Preslo $<$ preslo »prijevoj«), Velja glava i Vijenac. Toponim se Procijep odnosi na vrelo, a u Škaljarima na brdski predio u Vrmcu. Temelino apelativ procijep označuje usjek, a sekundarno vrelo.

4.2.1.1.2. Toponomijske metafore: Babin trbuh (Š), Bačvice (Š), Kamarina ${ }^{23}(<k a$ mara »soba«< tal. camara; D), Kolačić (< kolač »obao i šupalj kamen«; D), Kukmane $(<$ kukma »nadignut dio perja na glavi ptice«; Š), Lica $(<$ lice »predio okrenut Suncu«; D), Luk (D), Na orcu (< orca »jedrenje u smjeru protiv vjetra«< orca »uže kojim se veže jedro za jarbol« < mlet. òrza; JE II: 227; M), Nakraj pasa (< pas »pojas«; D), Nogalja (< nogalje »nogari«; RSKNJ 15: 783; P, Š), Oćali ${ }^{24}$ (< oćali »naočale «; D), Ralice (< ralo; D), Stepen ${ }^{25}\left(<\right.$ stepen »stepenica $<$ D D), Stoli $\left(<\right.$ stol $»$ prijevoj $<$ D D), Štit $\left(<\right.$ stit $^{26} »$ mjesto koje sprječava udare valova ili nalete vjetra $\ll$ D), Telovina $(<$ tela $» l a n e n o$ platno $<$ tal. tela "platno«; Radulović Lipovac 1981: 352; Š), Tumban (< tumban »ženski rubac oko glave«; ERHSJ III: 521; Š), U bok (<bok »plitka uvala«, M), Ždrijelo (< żdrijelo »uski prolaz«; D).

$\mathrm{U}$ ovoj su se skupini toponima odrazili nazivi dijelova ljudskoga tijela (bok i lice) i unutarnjih organa (trbuh i ždrijelo), građevinskih naziva (kamara i stepen), predmeta iz svakodnevne uporabe (bačva, nogalje »nogari« i oćali »naočale«), naziva odjevnih predmeta (pojas i tumban), oruđa (ralo) i prehrambenih proizvoda (kolač) te naziva za dijelove namještaja (stol).

\subsubsection{Toponimi s obzirom na razmještaj, oblik i izgled tla ili vode}

4.2.1.2.1. Toponimi uvjetovani smještajem zemljopisnoga objekta: Kutovo (P), Međubrde (Š), Pipoljevac (usp. Pipolje < prijepolje »prednji dio polja«; Skok 1950:112; Š), Podno polja (D), Pošpilje (< *Podšpilje; Š), Privino (< priviti; P).

U hidronimiji apelativ kut najčešće označuje mrtvi rukavac. U Prčanju je Kutovo potok koji teče od brda prema svjetioniku.

\subsection{Toponimi koji označuju oblik i površinska svojstva tla (izravni i} metaforični): Bezdanica (D), Debela greda (< debeo »širok « + greda »uočljiva stijena«; Š), Debeli brijeg (P), Duboki do (Š), Duga lastva (D), Glačice (usp. gladak; Š), Glatka

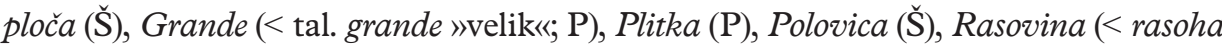

\footnotetext{
${ }^{22}$ Napominjem i da apelativ gabrio u bokeljskim govorima označuje manji zaljev ili uvalu.

${ }^{23}$ Kamarina je pećina.

${ }^{24}$ Također je riječ o pećini.

${ }^{25}$ Riječ je o oronimu, a istopisni toponim zabilježen je i sjeverozapadno od obrađenoga područ-
} ja, u Orahovcu (Krivokapić i Knežević 2017: 270).

${ }^{26}$ Apelativ štit u obalnoj toponimiji obično označuje zaklon od valova ili udara vjetra, a u kopnenoj nasip, mjesto do kojega ne dopire voda. Štit je vrh iznad crkve svetoga Eustahija u Dobroti. 
»račvasta udolina « $<$ soha $a^{27}$; D), Ravglavica ( $<$ Ravna glavica; $\left.\breve{S}\right)$, Ravna lastva $(<$ ravan + lastva »zaskok«; Š), Višnjice (usp. visok; D).

Na stjenovita područja upućuju toponimi u kojima je sadržan pridjev gladak (Glačice i Glatka ploča). Pridjev debeo u mjesnoj toponimiji označuje široke predjele, a na veličinu (veću površinu) zemljopisnoga objekta upućuje toponim Grande.

4.2.1.2.3. Toponimi koji se odnose na sastav i osobitosti tla ili vode: Babin ( $<$ baba ${ }^{28} » v e l i k i$ kamen, hridina«; P), Babina glava (usp. Babin; D), Bijeli (D), Bjelice (D), Blatina njiva (D), Cekovina (S), Crnica (P), Crvena greda (D), Crveni brijeg (S),

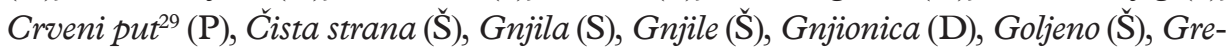
dine (D), Grudica (< gruda »okruglast kamen«; D), Igalo (< igalo »žalo«; P), Kamenica $(<$ kamenica $»$ prirodno udubljenje u kamenu«; Š), Kapi (usp. kapati; D), Kremenica

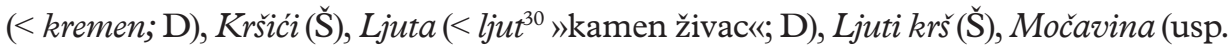
moča »mokrina《; D), Mokrice (D $\left.{ }^{31}\right)$, Mrko čelo (D), Na kamenicu (usp. Kamenica; Š), Njilovo ždrijelo (D), Parilo ${ }^{32}$ (< parilo »vrelo iz kojega voda isparava«), Pijavica ${ }^{33}$ (usp. piti; P), Pisteć (usp. pištet »vrelo iz kojega voda pišti«; P), Ploča (<ploča »kvadratni kamen«; P), Praševina (< prah; D), Prdusina (Š), Pržice (Š), Pržino (Š), Rinići (usp. rinuti; Š), Ripe (< ripa »stijena, hrpa kamenja«; Arj 14: 30; D), Rupe (P), Slana voda (D), Studenac (Š), Šuplii kam (< šupalj + kam »kamen«; D), Truć (D), Trulo ${ }^{34}(\check{S})$, Ušljivica (S), Velika lit $\left(<\right.$ lit $^{35} \gg$ hrid«, D), Velja greda $(\mathrm{P}), \operatorname{Vodnica}^{36}(\mathrm{D}), \operatorname{Vranji}(\mathrm{D}), \operatorname{Vranjine}\left(\check{S}^{2}\right)$, Vretovina (usp. vreti »vrijeti«; Š), Zelene lastve (D), Žuta lastva (Š), Žutina ${ }^{37}$ (D).

27 Soha je inače i slavenski poganski idol. Prvotno je apelativ označivao granu.

28 Riječ je o vrhu na Vrmcu. Baba je ujedno i ime ženskoga demona, personifikacija ženskoga pretka, možda eufemizam za božanstvo plodnosti (Brozović Rončević 1987: 123).

${ }^{29}$ Crveni put je i potok i put.

30 Opširnije o etimologiji naziva ljut vidjeti u Brozović Rončević (1999: 23). U srednjovjekovlju je zapisano latinsko ime rijeke Darantum.

31 Riječ je o dvama predjelima, jednome u zaseoku Kamenari te drugome nedaleko od Kokotove kule.

32 U Kotoru je Parilo zdenac iz kojega voda suklja velika količina vode. Hidronim je zapisan već 1159. (Lalošević 2016: 121), što svjedoči o znatnome stupnju slavenizacije samoga grada već u XII. stoljeću. U Kotoru vrlo često nakon nekoliko uzastopnih dana s velikom količinom padalina izbiju mnoga vrela. (usp. Stjepčević 1926: 53, 54)

33 Još su dva toponima Pijavica u Boki kotorskoj. U Bijeloj i kod Herceg-Novog (Magaš 2002: 69) i u Donjoj Lastvi Pijavica je gorski potok, stoga je vjerojatnije izvođenje od psl. *piti. U nesonimiji su istozvučni toponimi katkad metaforičnoga postanja ili su odraz vremenskih prilika.

\footnotetext{
34 Trulo je velika pećina.

35 Apelativ je zabilježen u Arj (VI: 122) s potvrdama iz dubrovačko-bokeljskoga područja.

36 Riječ je o pećini.

37 Žutina je jedna od pećina na dobrotskim brdima.
} 
Najveći se dio toponima iz ove skupine odnosi na različite vrste stijena i stjenovitih područja. Tako su se u toponimiji Kotorskoga zaljeva odrazili apelativi greda, gruda, kam ${ }^{38} /$ kamen, kremen, krš, lit, ljut, ploča, ripa i rupa. Na vrste tla upućuju toponimi koji sadržavaju pridjeve bijel (Bijeli i Bjelice), crven (Crvena greda i Crveni brijeg) i žut ${ }^{39}$ (Žuta lastva i Žutina), toponimi koji sadržavaju apelative gnjila »glina" (Gnjile, Gnjionica i Njilovo ždrijelo), prah (Praševina), toponimi koji upućuju na pjeskovite predjele (Pržice i Pržino) i nekvalitetna tla (Truć). Na izostanak biljnoga pokrova ukazuju toponimi Čista strana i Goljeno, a na njegovu prisutnost Mrko čelo, Vranji i Vranjine (ti bi toponimi mogli upućivati na predjele prekrivene crnogoričnom šumom) te Zelene lastve. Hidronimskoga su postanja toponimi koji se odnose na blatišta (Blatna njiva) i vrelišta (Kapi, Parilo, Pištec i Vretovina), područja s povremenim prisustvom vode (Močavina, Mokrice i Vodnica), potoke (Pijavica) i vododerine (Rinići), kakvoću vode (Ušljivica) te toponimi pridjevskoga postanja (Slana voda i Studenac). Pridjev crn u obalnoj toponimiji upućuje na predjele prekrivene morskom travom (Crnica). Vjerojatno su onomatopejskoga postanja toponimi Cekovina i Prdusina.

4.2.1.3. Odnosni toponimi: Donji Fankovići (M), Donji kučac (D), Gomila ispod Pušine (D), Gornje (D), Gornji fankovići (M), Gornji kučac (D), Gornji Muo (Š), Gornji vijenac (Š), Lazinice (D), Mala kapa (D), Mala ponta (D), Mala ripa (D), Mala rudina (D),

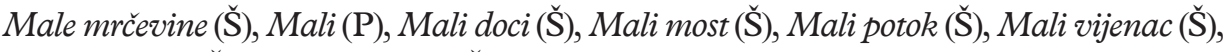

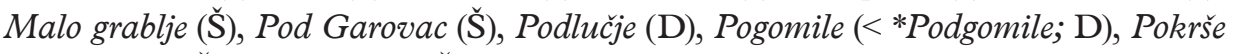
(< *Potkršje; Š), Podravnovo (Š), Potok iza Vitonjine (D), Starina ${ }^{40}(\mathrm{P})$, Velika jama (K),Velja gomila (Š), Velja kapa (D), Velja Kostanjica (P), Velja presla (Š), Velja rudina

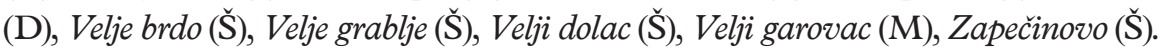

Dvorječni se odnosni toponimi najčešće tvore od pridjeva i imenice (npr. Donja smrekovina), a odnos se među samim toponimima najčešće iskazuje antonimnim parovima pridjeva, pri čemu antonimni par gornji - donji izražava prostorne, mali - velji (rjeđe veliki) kvalitativne, a stari - novi vremenske odnose (usp. Frančić-Mihaljević 1997-98: 88). U Kotorskome je zaljevu, kao i u istočnoj Hercegovini i na Braču, u tvorbi toponima najčešći prijedlog pod (usp. Šimunović 2004: 203, Vidović 2014b: 235).

\subsubsection{Toponimi motivirani nazivima biljaka i biljnih zajednica te dijelova} biljke: Bjelušinice (< bjelušina »Inula verbascifolia«; D), Borova šuma (D), Borovi (bor ${ }^{41}$

\footnotetext{
38 Apelativ kam također je svojstven dubrovačko-bokeljskome području (Arj 4: 788).

39 Riječ je o predjelima s glinovitim tlima. Predjele na kojima se vadi glina Bokelji nazivaju $b a-$ talo.

40 Starina je često ime vinograda.

41 U prošlosti je bor označivao tamnu šumu, pa je moguće da je ponegdje u Boki kotorskoj apelativ bor (ali izvan obrađenoga područja) uščuvan upravo u tome značenju.
} 


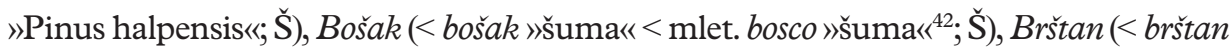
»bršljan, Hedera helix L.《; Š), Dračeva njiva $\left(<\right.$ drača ${ }^{43} » P a l i u r i u s$ spina-christi«; D), Drenovi (< drijen 》Cornus mas«; D), Dublje (< dub »hrast«; Š), Dumbrava $\left(<\right.$ dumbrava ${ }^{44}$ $»$ listopadna šuma«; $\breve{S}), U$ Fresine (< fresina »frijes, vrijes, Satureia montana«; Š), Grabov potok (< grab »Carpinus orientalis«; Š), Grabova prodo (usp. Grabov potok; D), Ispod brštana (usp. Brštan; P), Ispod oraha (< orah »Juglans«; D), Kostanj (< kostanj »kesten«; S), Kostanjica ${ }^{45}$ (usp. Kostanj; P), Kruševo (< kruša »kruška, Pyrus«; D), Kruška $a^{46}$ $(<$ kruška »Pyrus«; P), Liješće (<lijeha »gredica«; Š), Lišaji (D), Lorike (<lorika »lovorika, lovor, Laurus nobilis«; Š), Ljeskovac (<lijeska »Coryllus Avellana L.«, P), Mrče (< mrča »mirta, Myrtus communis«; Š), Mreževa greda (usp. mrijež »mlade stabljike, izdanci ili

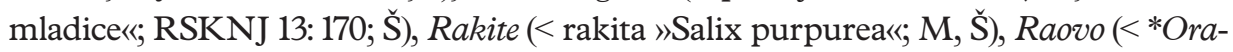
hovo < orah »Juglans«; M), Rastovac (< hrast 》Quercus«; D, P), Rištine (usp. vriština »biljna zajednica žutice i vrijesa«; P), Smreke (< smreka »Juniperus oxyceareus«; Š), Tr$\check{s c ́ a}(<$ tršća »trstik«), U borove (usp. Borovi; Š), Velja žuka (< žuka »Junceus«; P), Vrašti$c a^{47}(<$ vrijes »Satureia montana«; D), Vranjev vrijes (usp. Vraštica; Š), Vrbice (< vrba »Salix«; D), Zelenička greda (< zelenika »Phyllirea latifolia«; D), Žiljev kam (< žilj »Pancratium maritimum« < tal. giglio »jiljan«; Š), Žiljeva strana (usp. Žiljev kam; D), Žiljevo (usp. žiljev kam; D), Žuke (usp. Velja žuka; Š), Žukova glavica (usp. Velja žuka; Š).

U mjesnoj su se toponimiji odrazili mnogobrojni apelativi koji upućuju na postojanje raznorodnih vrsta grmolikih biljaka (bjelušina, brijest, drača, lijeska, lorika »lovor «, mrča »mirta«, vrijesak, zelenika i žuka »bazga«) i stablašica (drijen, dub, grab, kostanj »kesten « kruška, orah, hrast, smreka i vrba), a znatno su rjeđi odrazi naziva ukrasnih biljaka $\left(\check{z} i j^{48}\right)$. Okamenjeni su i nazivi za različite vrste šuma (bošak, dumbrava i liješće) i ostalih biljnih zajednica (riština »vriština« i tršća »trstik«). Odrazili su se ujedno nazivi dijelova biljaka (mrijež) i složenih organizama (lišaj).

4.2.1.5. Toponimi u svezi s nazivima životinja i životinjskih staništa: Bikovina (D), Bravov kam (< brav »mužjak ovce ili koze«; D), farčenica (<jarac ${ }^{49}$; D), Kobiošti$c a^{50}(<$ kobila; D), Kraj brloga (D), Kraulica (usp. kravulj »kraguj«; RSKNJ 10: 394; D),

${ }^{42}$ Opširnije o apelativu bošak u Vinja I: 60, 61. U Boki kotorskoj bilježi ga i Skok (ERHSJ I: 193).

$43 \mathrm{Na}$ širemu su području zabilježena i prezimena Dračevac (Herceg-Novi) te Dračis/Drača (Bar), ali je vjerojatnije izvođenje od biljnoga naziva.

44 Istovjetan je lik zabilježen u Istri (Arj 2: 885).

45 U Boki kotorskoj postoji istoimeno naselje napogled Perastu.

46 Kruška je ribarska pošta u Prčanju.

47 Vraštica je pećina u dobrotskim brdima.

48 Žilj je razmjerno čest motiv u hrvatskim petrarkističkim djelima.

49 Farčenica je pećina.

50 Kobioštica je također pećina. 
Lisičja voda (< lisica; Š $),$ Mededin potok $(<$ međed $»$ medvjed «; D), Sojak $(<*$ Sovljak $<$ sova; Š), Sovlje (Š), Vidrine (D), Vučja greda (< vuk + greda; D), Zebice (< zeba; Š).

Unutar gore navedene skupine najčešći su toponimi u kojima su se odrazili nazivi divljih (lisica, medvjed, vidra i vuk) i domaćih životinja (bik, brav, jarac i kobila), a rjeđe ptica (sova i zeba). Neki bi od navedenih toponima mogli biti i antroponimskoga postanja.

4.2.2. Toponimi imenovani prema drugim toponimima: Ljuta(D), Most od So-

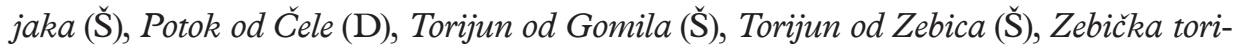
$n a^{51}(\check{S})$.

U ovoj su se skupini toponima odrazili mjesni hidronim Ljuta (naselje je Ljuta prozvano po rijeci) te oronimi Gomile, Sojak i Zebice.

\subsubsection{Toponimi motivirani ljudskom djelatnošću}

\subsubsection{Toponimi prema izgrađenim objektima i zdanjima}

4.2.3.1.1. Toponimi prema nazivima za gospodarske objekte: Gumanac (< gumno; Š), Kameni most ( $\check{\text { Š), Klačina (< klačina } » v a p n e n i c a, ~ m j e s t o ~ n a ~ k o j e m u ~ s e ~ g a s i ~ v a p-~}$ no" < dalm. calcaina; D), Konobica ( $<$ konoba; Š), Mosta ${ }^{52}$ (usp. most; Š), Pod magazine $(<$ magazin »skladište «; P), Pod solar ( $<$ solar »shod, mala terasa na koju vode stube ispred glavnih vrata «; Š), Prijeza ( $<$ prijeza $»$ preza, mali kameni stup na morskoj obali za koju se vežu lađe«< <al. presa; ERHSJ III: 129; P), Pristan (< pristan »pristanište«;

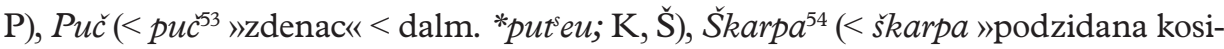
na« < mlet. scarpa; $\check{S})$, Spadola $(\check{S})$, Zgrade (D, Š).

Na poljoprivredne objekte upućuje toponim Gumanac, na raznovrsna osobna ili zajednička spremišta Konobica i Pod magazine, na ribolovno-pomorsku djelatnost Pristan, građevinsku Kameni most, Pod solar i Škarpa, stočarsku Zgrade, a na proizvodnju vapna Klačina. Hidronimskim je nazivom uvjetovan toponim Puč. Špadola (tal. Spadola) je bila građevinska tvrtka koja je poslovala u Škaljarima 1941-1943. te su nakon Drugoga svjetskog rata njezini objekti prenamijenjeni u stambene zgrade. Stradale su u potresu 1979.

${ }^{51}$ Riječ je o dvama predjelima, jednome kod Strijelišta, a drugome pod Lovćenom, kod negdašnje austrijsko-crnogorske granice.

52 Na predjelu se nalazila crkva Svetoga Križa, a Bratovština je Svetoga Križa dobila statut 1298.

53 U Boki kotorskoj danas je znatno potvrđeniji apelativ počuo.

$54 \check{S} k a r p a$ je put pored crkve svetoga Vicenca u Škaljarima. 
4.2.3.1.2. Toponimi kao odrazi naziva za obrambena zdanja: Fortin $(<$ fortin

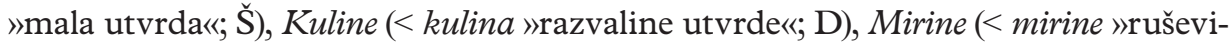
ne«; P), Stražišće (Š), Sveti Ivan (K).

Na razvaline negdašnjih zdanja upućuju toponimi Kuline i Mirina.

4.2.3.2. Toponimi prema obitavalištima te javnim prostorima i putovima: $D e-$ beli torijun (< debeo »širok « + torijun »serpentina $[<$ tal. torrione »velika utvrda, promatračnica; pokretna utvrda«; Lipovac Radulović 1981: 357; Š), Karuđina (usp. ca(r) rùggio »vrsta uske ulice«; Š), Kriva ulica (D), Krst (< krst »raskrižje«; D), Kućišta (Š), Plazno (< plaz »brdski put«; Š), Pričac (D), Rugovica (< ruga »zavojit put«; Š), Selo (P).

Iz ove se kategorije izdvajaju različiti nazivi za vrste prometnica hrvatskoga (plaz i pričac) i romanskoga postanja (karudina i torijun). Rugovica ${ }^{55}$ je predio iznad serpentina koje vode iz Škaljara put Trojice.

\subsubsection{Toponimi prema gospodarskoj djelatnosti}

4.2.3.3.1. Toponimi u svezi s poljoprivrednom djelatnošću: Duman $\left(<d u m a n^{56}\right.$ »vrt, voćnjak«; Lipovac Radulović 1981: 69; Š), Garovac (usp. gariti »paliti«, Š), Lanište (Š), Lazine (< lazina »krčevina«; D), Lećevišta (D), Lozica (Š), Masline (D, Š), Na poda (usp. Poda; Š), Pepelji laz (D), Poda (usp. pod »obradiva površina na više razina«; D), Prlina (< prlo »pasjeka«; usp. rum. a pirli »paliti, žeći«; ERHSJ III: 46; Š), Sad (Š), Trap (< trap »mladi vinograd«; Š), Vinogradac (D), Vr meda (D), Vrtline (D). Na vrste obradivih površina upućuju toponimi Duman, Na poda, Poda i Vrtline, na poljoprivredne kulture Lanište, Lećevište i Masline, na vinogradarstvo Lozica, Trap i Vinogradac, na stvaranje plodnoga zemljišta krčenjem Garovac, Lazina, Pepelji laz i Prlina, rasadnike $S a d$, a granice između posjeda Vr međa.

4.2.3.3.2. Toponimi u vezi sa stočarstvom: Mandra $\left(<m a n d r a^{57} » m j e s t o\right.$, ili koliba, na kojemu se ovce muzu«; Arj VI: 440; Š), Mali soliovac (< soliovac »solilo, mjesto na kojemu se ovcama daje sol«; Š).

4.2.3.3.3. Toponimi u svezi s ostalim gospodarskim granama: Banj (< banj $»$ plaža«; D), Klačevo čelo (usp. klak »vapno«; P), Pentar ${ }^{58}$ (< pentar »kamenolom«; P), Ta-

55 Skok (ERHSJ III: 166) bilježi apelativ ruga, koji izvorno označuje nabor, a pridjev rugan (u značenju svijen) dovodi u vezu s latinskim rūga te napominje kako među Albancima u Baru apelativ rruga označuje ulicu.

56 O etimološkim prijeporima vidjeti u Vinja I: 135. U Škaljarima Duman obuhvaća »livade ispod sadašnje župne crkve u Škaljarima, po prilici do Rakita« (Stanić 1978: 132).

57 Skok (ERHSJ II: 368) apelativ drži balkanskim grecizmom. U mjesne je govore vjerojatno ušao preko turskoga mandra.

58 Pentar je vrh u Vrmcu. Apelativ pentar Skok drži dalmatizmom (ERHSJ II: 671). I danas je živ u mjesnim govorima, a ujedno može označivati i bilo koju otvorenu rupu u zemlji. 
bačina $(<$ tabak »štavljač kože« < tur. tabak; D), Tunjola (< tunjola »tunja, tanko uže za ribarenje«; ERHSJ III; 523; P).

Na mjesta negdašnjih kamenoloma upućuje toponim Pentar, a vađenja vapna Klačevo čelo. Tabačina je, pak, bila predgrađe Kotora u kojemu su u srednjovjekovlju i ranome novovjekovlju stanovali štavljači kože, a Tunjola je ribarska pošta.

\subsubsection{Kulturno-povijesno uvjetovani toponimi}

4.2.3.4.1. Toponimi u svezi s upravnom i vojnom vlašću: Militarski park (D), Tamborje (< tambor »tabor «; D), Tamnica (D).

Militarski je park uredila i održavala austrijska vojska.

4.2.3.4.2. Toponimi u svezi s mjesnom poviješću i mjesnim predajama: Bolan-

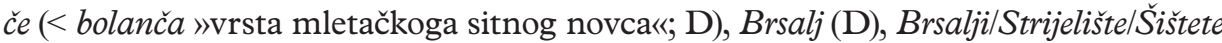
(Š), Tre sorelle / Tri sestre (P), Zli potok (D).

Isti zemljopisni objekt u Škaljarima nosi imena hrvatskoga (Strijelište), romanskoga (usp. tal. bersaglio »nišan «) i germanskoga (Šištete $<$ njem. schiessen) postanja (Stanić 1978: 132). Predio se Tre sorelle nalazi na Arđakovu u Prčanju. Riječ je o neobičnoj zgradi izgrađenoj u XIV. ili XV. stoljeću, najvjerojatnije ljetnikovcu vlasteoske obitelji Buća. Ona se sastoji od triju zasebnih dijelova. Po jednoj je predaji riječ o ljetnikovcu triju Bokeljki koje su u njoj tražile mir i odmor, a po drugoj su je izgradile tri sestre Filomena, Gracijana i Rina, koje su se zaljubile u istoga mladića - Jerka. Kako nije mogao oženiti sve tri djevojke, one su odlučile provesti život u izolaciji. Kako bi koja od sestara umrla, njezin bi prozor bio zazidan. Samo je prozor one koja je najkasnije umrla ostao nezazidan jer ga nije imao tko zazidati (Babić 2019: 40).

\subsubsection{Toponimi uvjetovani duhovnim i vjerskim životom zajednice}

\subsection{Toponimi motivirani imenima kršćanskih svetaca:}

\subsection{Toponimi motivirani vjerskim zajednicama te crkvenim građevi-} nama i posjedima: (A)rdakovo (: Arhandeo Mihovil; P), Arkandelovo (: Arhandeo

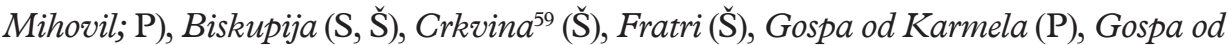
Vrta (D), Kaludrica (P), Kaluderica (S), Kapela (D), Krstac ${ }^{60}$ (P), Opatija (P, Š), Pod crkvom $^{61}\left(\check{S}_{\text {S), Podujam (: sveti Dujam; Š), Pologrina (: sveti Pelegrin }}^{62}\right.$; D), Popovi pasovi (D), Rt svetoga Matije (D), Sutorman (: sveti Roman; Š), Sveta vrača (usp. sveti vrači

59 Toponim je imenovan po ostatcima crkve Svetoga Križa izvan zidina.

${ }^{60} \mathrm{Na}$ Krstcu se po predaji nalazila crkva svetoga Antona.

${ }_{61}$ Toponim se odnosi na predio ispod crkve Gospe od Snijega.

${ }^{62}$ Rtove Pelegrin nalazimo na Šolti, Hvaru, Dugome otoku i Ugljanu te se ondje nalaze i crkve posvećene tomu svetcu (usp. Marasović-Alujević i Lozić Knezović 2011: 426). 
»sveti Kuzma i Damjan«; $\left.\mathrm{D}^{63}\right)$, Sveti Anton (P), Sveti Ilija (D, P, S), Sveti Ivan (D ${ }^{64}$, $\left.\mathrm{K}^{65}, \mathrm{P}^{66}\right)$, Sveti Krst (D), Sveti Matija (D), Sveti Nikola (P), Sveti Petar $\left(\mathrm{D}^{67}\right)$, Sveti Stasija $\left(\mathrm{D}^{68}\right)$, Sveti Toma (P), Trojica (: Sveto Trojstvo ${ }^{69}$; Š), Trojstvo (S).

Iznimno se bogata sakralna baština Boke kotorske odrazila i u mjesnoj toponimiji. Među toponimima u kojima su se odrazili titulari crkava česti su oni koji se odnose na ribarske pošte u blizini sakralnih objekata (primjerice, Sveti Anton, Sveti Nikola i Sveti Toma). Toponim Sutorman u Škaljarima pripada skupini toponima tvorenih pridjevom san(c)tu(s) (sanctus Romanus) ${ }^{70}$ te dosad nije zabilježen u hrvatskoj toponomastičkoj literaturi. Toponim se Fratri može svrstati i u skupinu toponimijskih metafora jer se njime označuju istaknute stijene (usp. Marasović-Alujević i Lozić Knezović 2011: 423). Na crkvene posjede upućuju toponimi Biskupija, Opatija i Popovi pasovi, a hidronimi Kaludrica ${ }^{71}$ i Kaluderica na blizinu sakralnih objekata uz vrelo.

\subsection{Toponimi uvjetovani prežitcima pretkršćanskih vjerovanja: Vilina pećina $(\mathrm{D})$.}

4.2.3.5.3. Toponimi uvjetovani ostalim elementima duhovne kulture: Gomile ${ }^{72}$ (< gomila $»$ hrpa nabacana kamenja«< psl. mogyla »grobni humak«; D), Šarena gomila (P), Zakopane (̌̌). Topinimi iz ove skupine mogli bi upućivati na grobišta.

63 Riječ je o dvama predjelima, jednome na kojemu se nalaze ostatci crkve Svih svetih, koja se spominje od 1503., a koju je 1889. obnovio kapetan Marko Andrić, te drugi na kojemu se počela graditi istoimena crkva, koja nije dovršena zbog manjka sredstava, pa je prenamijenjena u stambenu zgradu.

64 U Dobroti se nalaze dvije crkve svetoga Ivana. Jedna, izgrađena najvjerojatnije polovicom XVI. stoljeću, iznad zaseoka Kamenari, te druga, nedovršena, s konca XVIII. stoljeća i smještena na samoj obali.

65 Sveti Ivan je tvrđava na vrhu kotorskih zidina prozvana po crkvici koja je bila u njoj smještena. XIII. stoljeća.

${ }^{66}$ Riječ je o pošti i zdencu kod crkvice svetoga Ivana Krstitelja, koja najvjerojatnije potječe iz

67 Toponim se odnosi na crkvu u Ljutoj izgrađenu 1780.

68 Starija se crkva svetoga Eustahija spominje 1332., a mlađa se počela graditi 1762.

69 Riječ je o gorskome sedlu iznad Škaljara u kojemu su nekoć obitavali pustinjaci.

70 Usp. oronim Sutorman kod Bara (bilježi ga i Skok, ERHSJ III: 365) u povijesnim vrelima zabilježen i kao Sutroman.

71 Skok (ERHSJ II: 129) bilježi lik Koludrica.

72 Apelativ gomila u mjesnome govoru najčešće označuje grobni humak, neovisno o tome iz kojega povijesnog razdoblja potječe (tako primjerice može označivati i ilirsko grobište). Na Braču pak gomila označuje »hrpu kamenja nastalu trijebljenjem kamenja« (Šimunović 2004: 218). 


\subsubsection{Toponimi antroponimijskoga postanja}

\subsubsection{Višerječni toponimi antroponimijskoga postanja}

4.2.4.1.1. Toponimi od antroponima i zemljopisnoga naziva: Balabinov do (D), Boškov potok (Š), Benov do (D), Bujina pećina (Š), Daletina pećina (D), Daletino točilo (D), Domaćinov kamen (S), Grgurov potok (D), Fagoševo točilo (D), fanoševa greda (D), Lundrića brijeg (P), Marevo čelo (P), Markov do (ک̌), Markov rt (P), Meče-

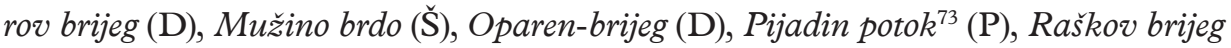
(D), Staničin brijeg (Š), Tičin kam (D), Tomina glavica (D), Zubanova glavica (D), Žarkov kam (Š).

U ovoj skupini višečlanih toponima antroponimnoga postanja uz antroponim najčešće dolaze odrazi naziva geomorfoloških oblika krša: do (3), pećina i kam (2) te kamen i greda (1). Podjenako su zastupljeni odrazi oronimijskih naziva: brijeg (5) te brdo, čelo, glava i glavica (1). Razmjerno su česti i odrazi hidronimijskih naziva: potok (3) i točilo (1). Usto se odrazio i uzmorski naziv $r t$ (1).

4.2.4.1.2. Toponimi od antroponima i gospodarskih naziva te naziva stambenih objekata i prometnica: Brguljanove stare torine ( $(\breve{S})$, Cucin dolac $(\breve{S})$, Cucin palac (M), Čepićeva lastva (Š), Don Nikova lazina (P), Duševo gumno (Š), Kokotova kula (D), Lukovo gumno (M), Marevo/Marovo gumno (D), Matovi doci (Š), Mijov dolac (M), Srdarove torine (Š), Stakina torina (D).

Najčešći su odrazi naziva poljoprivrednih čestica i gospodarskih objekata: gumno (5), dolac (3) te lastva i lazina (1). Ujedno su se u mjesnoj toponimiji odrazili stočarski (kao što je torina) i graditeljski (kao što su kula i palac) nazivi.

4.2.4.1.4. Toponimi od antroponima i naziva uvjetovanih duhovnim i vjerskim životom zajednice: Lukovića opatija (P), Petrusinovo selo(D), Žbutegića opatija (P).

\subsubsection{Jednorječni toponimi antroponimijskoga postanja}

4.2.4.2.1. Toponimi pridjevskoga postanja: Antićevo (M), Babićevo (ك̌), Bajevo (M), Bajlovo (D), Bakušinovo (Š), Banovo (Š), Barbijerovo (P), Benovo (D), Biokovo (S), Dobrilovina $(\mathrm{D}), \operatorname{Draganje}^{74}(\mathrm{P})$, Franovo $(\check{\mathrm{S}})$, Franzinovo $(\check{\mathrm{S}})$, Girino $(\mathrm{P})$, Goražda $(\check{\mathrm{S}})$,

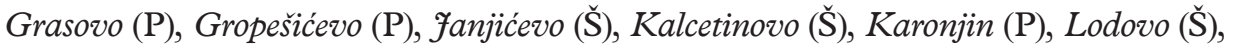
Marićevo (P, Š), Marinćetićevo (P), Marovo (M), Matijevo (Š), Medvjedovo (P), Mrljacinovo $(\breve{S})$, Ostojne (<*Ostojine; D), Ostojno (<*Ostojino; D), Palićevo $(\check{\mathrm{S}})$, Palinovo (P, S), Picovo (M), Podivanovo (P), Polarevo (P), Puncijelino (P), Radatovo (D), Radinovo (M), Ratkovo (P), Ridanovo (M), Sabovo (Š), Sinkovićevo (P), Slaničarovo (M), Sreda-

\footnotetext{
73 Toponim je zapisan početkom XIX. stoljeća.

${ }^{74}$ Predio se naziva $i$ Čisti vrh.
} 


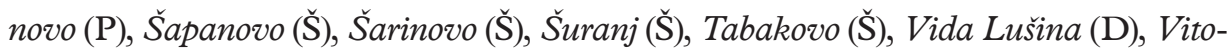
njina (D), Zlatarevo (P).

Starijemu jezičnom sloju pripadaju toponimi tvorenih posvojnim sufiksom *-j675: Draganje, Goražda (<*Gorazdova) i Šuranj.

4.2.4.2.2. Toponimi tvoreni toponomastičkim sufiksima: Batkovina (ك̌), Boljevica (D), Brajnica (pećina; P), Brkovica (P), Galinica (D), Fanjevica (D), Ferovica (P), Karampana $^{76}(\mathrm{~K})$, Krilovina (M), Krlanovina (D), Kučevo (P), Landruša (D), Lekovina (P), Linjevo (D), Lorenčina (M), Lukačevina (D), Mačkovina (Š), Marošina (P), Marovina (D), Matolovina (Š), Metkovine (D), Milakovica (D), Milovcina (P), Mirćevina (Š), Mitrovica (P), Ninovica (D), Pavlovica (P), Perovina (P), Peruškovo (Š), Petrovina (D), Radmilovica (D), Ribarica (D), Roljovina (Š), Srgovica (D), Starčevine (D), Šantulja (D), Tripkovina (D), Vitaliica (D).

Toponimi su koji pripadaju ovoj skupini tvoreni sufiksima koji označuju pripadnost (-ica, -ina, -ovica/-evica, -ovina/-evina, -ulja, -uša).

4.2.4.2.2. Antroponimi u funkciji toponima: Arbanasovići (D), Bagazoni (D), Bakalići (D), Bakovići (D), Basari (Š), Brkanovići (Š), Bilafer (D), Čičiće (M), Dančulovići (P), Dončići (Š), Đurovići (S), Glavati (P), Ilići (D), Ilijaševići (D), fanoši (D), Fanjiće (Š), Kamenari (D), Kandioti (D), Kapovići (D), Kavalin (D), Kitići (P), Kličići (M), Marovići (D, M), Mijatovići (D), Milovići (D), Miševići (P), Mišulić (D), Miros ${ }^{77}$ (P), Mrvicicici (P), Oparene (D), Paskovići (M), Pavličeviće (P), Petani (P), Petkići (P), Pet(r)ovići (D, M), Pijerovići (D), Račete (D), Radomiri (D), Radoviće (P), Sablici (M), Šalijagići (D), Škaljarin (P), Tomići (D), Tripkovići (D), Uljarevići (M), Veroniće (P), Veronići (Š), Vukićevići (M), Vušovići (D), Žbutegiće (P), Žabatići (Š), Žutkići (Š).

Vrlo su često kao temeljni potvrđeni akuzativni likovi ojkonima (npr. Fanjiće, Oparene, Pavličeviće, Radoviće, Veroniće i Žbutegiće ${ }^{78}$ ). Uzimanje gotovih osobnih imena za imenovanje nije odlika slavenskih jezika, nego je pojava mlađega postanja, koja je u manjoj mjeri potvrđena i u Boki kotorskoj (npr. Bilafer, Kavalin, Petani i Škaljarin).

Od kršćanskih imena u toponimiji su se Kotorskoga zaljeva odrazila osobna imena Antić $(<$ Anton), Frano, Grgur, Ivan, fanoš $(<$ fano $<$ fan $» I v a n \ll)$, Fanja, fero (< Feronim), Luka, Lukač $(<$ Luka), Maro ( $<$ Marin), Marko, Matija, Mato ( $<$ Matej

75 Usporedi Šimunović 2004: 224.

${ }^{76}$ U Kotoru je stanovao odvjetak mletačke obitelji Rampani, po kojemu je javni zdenac u Kotoru prozvan. O etimologiji riječi karampana (kojom se u Dalmaciji ponajprije označuje dotrajali brod ili babetinu, a u Kotoru i na Hvaru i zlo govorenje) vidjeti u Vinja II: 64.

77 Miroš je vrelo.

${ }^{78}$ Slična je pojava vrlo često potvrđena i u Zažablju (Vidović 2014b: 179). 
Matija), Mijo (usp. Miho < Mihajlo/Mihovil $\left.{ }^{9}\right)$, Pavao, Pero ( $<$ Petar), Petrusina $(<$ Petrusa $<$ Petar), Roljo ( $<$ Roko; Š), Srg ${ }^{80}$, Toma, Vital i Vitonja $(<$ Vito $<$ Vital). U mjesnoj su se toponimiji odrazila ujedno narodna imena Bajlo $(<$ Bajilo $<$ Bajo; hip. od Bratislav), Batko (< Bato; hip. od Bratislav), Bioko ( $<$ Bjelimir/Bjeloslav), Boško $(<$ Božo $<$ Božidar), Dobrilo (< Dobre $<$ Dobromir/Dobroslav/Dobrovoj), Dragan ( $<$ Drago $<$ Dragomir/Dragoslav), Duša/Dušo $(<$ duša), Gorazd, Milak ( $<$ Milo $<$ Miloslav), Mirko $(<$ Miro $<$ Miroslav), Miroš $(<$ Miro $<$ Miroslav), Ostoja, Radat $(<$ Rade/Rado $<$ Radimill Radomir/Radoslav), Radin (< Rade/Rado < Radimil/Radomir/Radoslav), Radimil, Ratko ( $<$ Rade/Rado $<$ Radimil/Radomir/Radoslav), Sredan (usp. Sredoje $\left.{ }^{81}\right), S_{\text {Stanica }}{ }^{82}$ $(<$ Stana $<$ Stanislava $)$ i Žarko. Zabilježeni su i odrazi stranih imena Franzin i Lodo $\left(<\right.$ tal. Lodovico $\left.{ }^{83}\right)$. Nije moguće nedvojbeno ustvrditi postanje osobnih imena Daleta i fagoš. Prvo se može povezati s narodim imenom Dabiživ, ali i kršćanskima Damjan i Danijel. Osobno se ime fagoš u Crnoj Gori nadijevalo djetetu koje se rodilo nakon očeve smrti ili čija je mati umrla pri porodu, a moguće ga je povezati ili sa složenim imenom fagomir (Grković 1977: 102) ili sa ženskim faga »Agata«. Zabilježeni su i odrazi dvočlane imenske formule don Niko i Vido Lušin.

Ujedno su se odrazila i mnogobrojni pridjevci i prezimena Babić $(<b a b a)$, Bagazoni ${ }^{84}$, Bajo (< bajo »mali brat «), Baković (< bak »priplodni vol «), Balabin (možda od tal. imena Balbino), Ban (ović) (< ban), Barbieri (< barbijer »vidar, brijač «), Bene $e^{85}$ $\left(<\right.$ Benedikt), Bolica ${ }^{86}$, Brguljan ( $<$ Brguli $\gg z a s e l a k$ na Luštici $)$, Brkanović $(<$ brkan $<$ brko »brkata osoba«), Bujović (<Bujo < Budimir/Budislav), Cuca, Čepić (usp. čepati »lomiti, kidati, kršiti $\ll)$, Čičić $(<$ čiča $)$, Dančulović $(<$ Dančul $<$ Dančo $<$ Danijel $)$, Dončić $(<$ Don-

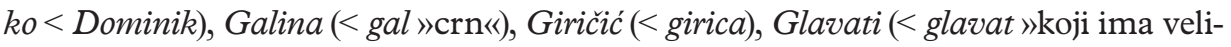
ku glavu«), Graso (usp. tal. grasso »debeo, mastan«), Hoh (vjerojatno od Hoch $<$ njem. hoch »visok«), Ilić $(<$ Ilija), Ilijašević $(<$ Ilijaš < Ilija), Fanjić $(<$ fanja), Kalceta $(<$ kalceta

79 Oba su lika potvrđena među katolicima istočno od rijeke Neretve od srednjovjekovlja.

80 Riječ je o liku kršćanskoga imena Srđ s očuvanim velarom (ERHSJ III: 318), koji se u Boki kotorskoj okamenio i u prezimenu Srgotić u Bijeloj.

81 Za narodno ime Sredoje Milica Grković (1977: 184) navodi kako je riječ o zaštitnome imenu koje se nadijevalo djeci rođenoj u srijedu.

82 U Kotoru je u XIII. stoljeću zabilježen pridjevak de Staniça (Jireček 1962: 233), pa nije isključeno ni da je riječ o prežitku srednjovjekovnih imovinskih odnosa

83 Riječ je o nahodišnome imenu (Šimunović 2006: 347).

${ }^{84}$ Bagazoni je talijansko prezime, pa je moguće da je riječ o nekoj obitelji koja je stanovala u Dobroti. Pritom je zanimljivo da se prezime Bagazon(i) spominje i tijekom opsade Korčule 15. kolovoza 1571. od strane turskoga potkralja Alžira.

85 Obitelj de Bene spominje se u Kotoru 1330. (Jireček 1962: 49), a u srednjovjekovlju je potvrđeno osobno ime Bene, pokraćeni lik kršćanskoga imena Benedikt.

86 Jireček (1962: 250) kotorski pridjevak i prezime Bolica (zbog likova Bouoliça i Biualiça) povezuje s apelativom bivol. 
»čarapa «), Kamenarović ( $<$ kamenar), Krilović $(<$ Krilo $<$ Kristofor), Leko $(<$ Leko »Aleksandar «), Lorencin (tal. Lorenzo »Lovrjenac, Lovro«), Luković (< Luka), Marić $(<$ Mara $<$ Marija), Marinčetić $(<$ Marinčeta $<$ Marinče $<$ Marin), Maroš $(<$ Maro $<$ Marin), Marović (nekoć Marojević < Maroje < Maro < Marin), Mečer (vjerojatno od Metscher), Metković $(<$ Metko $<$ Medo $<$ Medvjed), Mijatović $(<$ Mijat $<$ Mijo $<$ Mihajlo/Mihovil), Milović (< Milo < Miloslav), Mišević (< Miše Mihajlo/Mihovil), Mitrović $(<$ Mitar $»$ Dimitrije $\ll)$, Mrvica, Oparenović $(<$ Oparen), Palić $(<$ Pale $<$ Pavao), Pasković ( $<$ Pasko »Paskval«), Pa (u)lina $(<$ Paulina $<$ tal. Paulo »Pavao $\ll)$, Pavličević $(<$ Pavlic $<$ Pavao), Perušković $(<$ Peruško $<$ Peruša $<$ Pero $<$ Petar $)$, Petani $(<$ Petan $<$ Peto $<$ Petar), Petkić $(<$ Petko < Peto < Petar), Petović $(<$ Peto $<$ Petar), Petrović $(<$ Petar $)$, Pijade (<pijade »vojnik pješak «< tur. piyade; Škaljić 1966: 518), Pijerović $(<$ Pijero $<$ tal. Piero $\gg$ Pero $\ll)$, Račeta $^{87}(<$ Rače $<$ Rako $<$ Radomir/Radoslav), Radomir(i) $(<$ Radomir), Radović $(<$ Rade/Rado $<$ Radomir/Radoslav), Sablić $(<$ sablja), Sbutega (mjesni lik Žbutegić; možda od zbutati »nagurati, strpati; smetati, zbrkati«; RSKNJ 6: 646), Serdarević $(<$ serdar), Sinković, Tičić (< tica »ptica $)$, Starčević $\left(<\right.$ starac), Surana/Šurana ${ }^{88}$, Tomić $(<$ Toma), Tripković $(<$ Tripko $<$ Tripo $<$ Tripun), Uljarević $(<$ uljar), Verona (mjesni lik Veronić; < Verona), Vukićević $(<$ Vukić $<$ Vuk), Vušović $(<$ Vušo $<$ Vuk), Zambata (mjesni lik Žabatić; možda od zamba »vrsta biljega na ušima ovaca i koza ili vrstu rezbarskoga oruđa«; RSKNJ 6: 116), Zuban (<zub) i Žutkić $(<z ̌ u t k o<z ̌ u t)$.

U mjesnoj su se toponimiji okamenili i nadimci: Arbanasović $(<$ Arbanas $\gg$ Albanac«; obiteljski nadimak dijela Vulovića u Dobroti), Bakalić (< baka/bak; obiteljski nadimak dijela Dapčevića u Dobroti), Bakuša (< baka/bak), Basari (< tal. basso »nizak, malen«), Bilafer (< bilav »bilan, pojas koji veže konjsku uzdu za prsa konja, tako da konj ne može suviše dizati glavu i propinjati se« < tur. bilan; Škaljić 1966: 142; nadimak ${ }^{89}$ dijela Kosovića u Dobroti), Brko (< brk), Gropeša (< grop »čvor « < tal. groppo), Kapović (< kapo "glavar, starješina» < tal. capo), Karonja $(<$ karonja »pokvarenjak, nitkov« < tal. carogna), Kavalin ( $<$ tal. cavallo »konj《), Kitić $(<$ kita), Kličić $(<$ klicati), Kokot (< kokot »pijetao «), Krlan ( $<$ Krle $<$ Kristofor), Kučić (usp. kučak»pas«), Landru$\check{s a}$ (usp. landrati »bescilino lutati «), Linjo (usp. olinjati se), Lundrić (< lundra »raspuštenica «), Mačak, Matolovina ( $<$ Matola $<$ Mato $<$ Matej/Matija), Medvjed ${ }^{90}$, Mišulić $(<$ Mišula $<$ miš/Mišo), Mrljača (usp. mrljati), Muž, Pic, Polar (< polar »osoba koja odlama pole, velike stijene«), Puncjela ( $<$ puncjela $» d j e v o j k a, k l a r i s a \ll)$, Ribar, Riđan ( $<$ rid »riđokos« / riđan »konj riđe dlake«), Slaničar (< slaničar »solilac, radnik u solani «),

87 Prezime Račeta tvoreno od istopisnoga imena navodi Arj (12: 849).

88 Rod Surana/Syrana jedan je od srednjovjekovnih kotorskih vlasteoskih rodova (Čulić 1996: 206; Stjepčević 1929: 22).

89 U Strpu je Bilafer prezime.

90 U Kotoru je u srednjovjekovlju zabilježeno i osobno ime Medvjed (Čulić 1996: 199). 


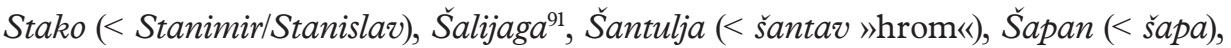
Šare $(<$ šare $» k o j i$ ima pramenove različite boje«), Tabak (< tabak»štavljač kože«) i Zlatar.

\subsubsection{Toponimi etničkoga, ktetičkoga ili etnonimskoga postanja: Crnogorski pazar (D), Dobrotska gora (D), Dobrotske strane (D), Levantska ulica (Š), Špiljarska torina $(\breve{S})$, Voda stolivska $(\mathrm{S})$.}

Etnonomskoga je postanja toponim Crnogorski pazar. Na Crnogorskome pazaru, koji je nekoć bio spojen s Dobrotom kamenim mostom, Crnogorci su tijekom mletačke i austrijske vladavine prodavali svoje proizvode te su u Kotor smjeli ući samo nakon što odlože oružje. U u mjesnoj su toponimiji ujedno uščuvani ktetici dobrotski $(<$ Dobrota), levantski $(<$ Levanat $» i$ istočno Sredozemlje $\ll)$, stolivski $(<$ Stoliv) i špiljarski $(<$ Śpiljari $»$ naselje sjeverno od Kotora, u sjevernome podgrađu Kotorskih zidina«).

4.2.6. Toponimi nejasna postanja ili motivacije: Daosine (D), $\operatorname{Mocilj}^{92}$ (D), Mončulovo $^{93}$ (D), Mržep ${ }^{94}$ (S), Ocinac (D), Peluzica ${ }^{95}(\mathrm{M})$, Plagenti ${ }^{96}(\mathrm{D})$, Sviška (Š), Škrdio donji ${ }^{97}$ (D), Škrdio gornji (D), Škurda ${ }^{98}(\mathrm{D}, \mathrm{K}), \operatorname{Tuki-do}(\mathrm{D}), \operatorname{Vrmac}^{99}$ (M, P, S, Š), Zapisani (S).

91 Šalijaga/Šalijagić je bio obiteljski nadimak dijela dobrotskih Klačevića. Moguće je da je nadimak nastao po uzoru na dvočlana turska imena (usp. Hasan-aga, Smail-aga i sl.).

92 Usp. mocira »kameni suhozid« (usp. razjednačivanje $r>l j$ u kurir $>$ kurilj). Kako je navedeni apelativ u Boki kotorskoj neproziran, moguće je i ukrštavanje sa slavenskim apelativima moča i močilo.

93 Toponim bi mogao potjecati od nekoga antroponima (usp. žensko ime Momčula u bugarskome osobnoimenskom fondu; Ilčev 2012: 460).

94 Riječ je o potoku. Skok (ERHSJ III: 190) drži »prvi dio $m r \check{-}$ « toponima neprozirnim, a drugi dio povezuje s mediteranskom hidronimskom osnovom *ap-.

95 Stanić (1978: 141) toponim povezuje s grčkim pelós 'mulj, glib, močvara'. Oko Peluzice je više prokopa i vrelo, pa je semantički tumačenje uvjerljivo s tim da je toponim morao proći kroz dalmatski filtar.

96 Toponim je dosad nastojao protumačiti Miljenko Lončar (2002: 257-262) dovodi u vezu s participom aorista pasivnoga glagola koji je zabilježen u Porfirogenetovu u participu mediopasivnome glagola u jednini srednjega roda (peplygménon »zbijeno«), kojim se opisuje Kotor kao mjesto »stiješnjeno i zbijeno«. Lončar ujedno traži i dalmatske usporednice.

97 Toponim valja usporediti s toponimima Skradin i Skarda (otočić između Paga i Silbe) te $S k r$ $d a$ (kod Luna i Novalje) za koje Skok pretpostavlja da su ilirski (ERHSJ III: 268, 274). Za Škrdio Skok navodi da je u dalmatskome mogla biti apelativom.

98 Marković (2006: 25) drži da je hidronim Škurda u Kotoru usporediv s hidronimom (potokom) $\breve{S} k u r t a$ kod Bara te ih povezuje s latinskim excurtare. Po njegovu tumačenju $\breve{S} k u r d a$ bi bila »kratka rijeka«. Skok hidronim drži usporednim s toponimom Škrdio. U Dobroti je Škrdio vrelo, ali i šire područje.

99 Toponim Vrmac usporediv je s imenom srednjovjekovnoga grada Vrma koji Konstantin Porfirogenet u X. stoljeću nazivlje Ormos. Petar Skok dovodi taj toponim u svezu s imenom grada Eremum, 


\section{Jezična raslojenost toponima}

Burna je povijest Boke kotorske ostavila traga u mjesnoj toponimiji. Iako je cjelokupna mjesna toponimija već stoljećima isključivo slavenska, u njoj su se okamenili prežitci različitih inojezičnih sustava, među kojim su najzastupljeniji romanski. Supstratni se dalmatski sloj odrazio u ojkonimiji (Kotor, Muo, Prčanj, vjerojatno posredno i Plagenti), hidronimiji (Boljun, Gurdić, Škrdio, Škurda) te se iz njega razaznaju i prežitci predrimskoga sloja. U mjesnoj su se toponimiji odrazili različiti apelativi dalmatskoga postanja, čiji su odrazi razmjerno često zastupljeni u istočnojadranskoj toponimiji (klačina, mirina, mrča, peča, ploča, puč, spila, žuka), ali i neki razmjerno rijetki (pentar). U Škaljarima je zabilježen toponim Sutorman (: sveti Roman) tvoren dalmatskim pridjevom san (c)tu(s), koji dosad nije bio naveden u hrvatskoj onomastičkoj literaturi. Toponimi tvoreni tim pridjevom označuju prostore snažnijega slavenskog naseljavanja te pokrštavanja do konca X. stoljeća (Šimunović 2005: 123). Rana je prilagodba je romanskih apelativa i toponima razvidna na primjerima kao što je Gurdić, kojemu je, uz fonološku prilagodbu toponimskoga lika, pridodan slavenski nastavak -ić.

Od adstratnih je slojeva najzastupljeniji talijanski (uglavnom mletački). U mjesnoj su se toponimiji najčešće odrazili graditeljski i kulturno-povijesni nazivi talijanskoga (mletačkoga) postanja (fortin, kamara, prijeza, solar, škarpa), a rjeđe i nazivi biljnih zajednica (bošak). Talijanski toponimi Tre sorelle i San Giovanni usporedno se upotrebljavaju i danas uz hrvatske Tri sestre i Sveti Ivan.

Znatno su rjeđi tragovi adstratnoga turskog sloja, uščuvani najčešće u povijesnim toponimima u kojima se odražava robna razmjena između stanovnika mletačke Boke kotorske i crnogorskoga zaleđa (Crnogorski pazar i Tabačina). Rubno nalazimo i utjecaj albanskoga (pri čemu treba imati na umu da se albanski stočari na Vrmcu spominju još u Kotorskome statutu iz kasnoga srednjovjekovlja) i njemačkoga (iz razdoblja austrijske uprave) jezika.

Slavenski se likovi toponima bilježe barem od XII. stoljeća (npr. hidronim $P a$ rilo). U temeljnome su slavenskom sloju uščuvani danas neprozirni hidronimijski apelativi kao što su *mer- »vododerina, točilo« (Mramor) i tinja »blato« (Tinjak). Rijetki šćakavski prežitci u mjesnoj toponimiji (Stražǐ̌će $e^{100} \mathrm{u}$ Škaljarima) potvrđuju tezu Josipa Lisca (Lisac 2003: 122-124) da bi hrvatski bokeljski govori mogli pripadati

\footnotetext{
a P. Šobajić i S. Pujić drže da je riječ o odrazu slavenskog apelativa vrm koji je označivao »zemljišta izrovljena potocima« (Pujić 2003: 163). Oronim Vrmac zabilježen je i u Zažablju, u naselju Babin Do kod Neuma (Vidović 2014b: 284).

100 Šćakavske odraze u toponimiju nalazimo i u susjednoj istočnoj Hercegovini u toponimiji hrvatskoga povijesnog prostora od Hutova do Dubljana (Vidović 2014b: 181).
} 
zapadnoštokavskome narječju. U mjesnoj toponimiji zabilježeni su i neki ikavizmi (Pričac).

\section{Zaključak}

U ovome se radu obrađuju toponimi Kotorskoga zaljeva na području naselja Dobrota, Kotor, Muo, Prčanj, Stoliv i Škaljari. U uvodu su iznose temeljni povijesni i demografski podatci bitni za razumijevanje toponimijske slike obrađenoga područja. Naime, u mjesnoj se toponimiji nalaze odrazi srednjovjekovne romansko-slavenske simbioze svojstveni cjelokupnomu istočnojadranskom obalnom prostoru, čijim su najrazvidnijim prežitkom hagionimi kao što je Sutorman (sveti Roman). U mjesnoj su se toponimiji ujedno odrazili i mnogi titulari bokeljskih katoličkih crkava, kojih samo u Kotoru tridesetak (Stjepčević 1929: 19). Oni se nisu odrazili samo na područje uza same crkve i posjede Katoličke crkve, njima su motivirani i mnogi hidronimi (uglavnom zdenci) i ribarske pošte. Toponimi antroponimskoga postanja upućuju na negdašnje zemljišno-posjedničke odnose te pomorsku tradiciju. U njima su se ponajvećma odrazila osobna imena srednjovjekovnih stanovnika Kotora te prezimena pomoraca i posjednika ${ }^{101}$, uglavnom hrvatskoga i rjeđe romanskoga podrijetla, što odražava pretežito hrvatski i katolički karakter središnjega dijela Boke kotorske do početka XX. stoljeća.

U mjesnoj su se toponimiji odrazile geomorfološke značajke Kotorskoga zaljeva (osobito različiti tipovi voda te krških oblika) te se u njoj ogledaju različiti jezični slojevi. Od inojezičnih utjecaja očekivano je najzastupljeniji romanski (supstani i adstratni), poglavito u obalnoj toponimiji, a prikupljeni su podatci i dijalektološki relevantni (npr. šćakavski toponim Stražišće u Škaljarima). Sve to upućuje na nužnost daljnjih toponomastičkih istraživanja.

101 Usp. i Babić 2019: 35-43. 


\section{LITERATURA}

ARj = Rječnik hrvatskoga ili srpskog jezika. 1881. - 1976. JAZU. Zagreb.

Babić, Vanda (2019). Boka kotorska - zaljev svetaca i hrvatske kulture, Jutarnji list, Zagreb.

Bezlaj, France (2003). Zbrani jezikoslovni spisi I, Založba ZRC, ZRC SAZU, Ljubljana.

Brozović Rončević, Dunja (1987). Tragovi poganskih, kršćanskih i islamskih kultova u toponimiji, Zbornik 6. jugoslovenske onomasticke konferencije, Odeljenje jezika i književnosti

Brozović Rončević, Dunja (1997). Hidronimi s motivom vrelišta na povijesnome hrvatskom prostoru, Folia onomastica Croatica 6, 7-40.

Brozović Rončević, Dunja (1999). Nazivi za blatišta i njihovi odrazi u hrvatskoj toponimiji, Folia onomastica Croatica 8, 1-40.

Crkvenčić, Ivan; Schaller, Antun (2007). Promjene etničkoga sastava Boke kotorske (1910. - 2003. g.) s posebnim osvrtom na veliko smanjenje broja Hrvata, Hrvatski geografski glasnik 69/1, 69-100.

Čače, Slobodan (1998). Promjene u naseobinskom sustavu kasnorimske Dalmacije: tragovi u toponimiji, Folia onomastica Croatica 7, 23-40.

Čilaš Šimpraga, Ankica; Ivšić Majić, Dubravka; Vidović, Domagoj (2018). Rječnik suvremenih hrvatskih osobnih imena, Institut za hrvatski jezik i jezikoslovlje, Zagreb.

Čulić, Gracijela (1991). Struktura antroponimije Boke kotorske u XIV. i XV. stoljeću, Onomastica fugoslavica 14, 87-132.

Čulić, Gracijela (1996). Antroponimija Boke kotorske (od prvih pisanih spomenika do kraja XIX vijeka), Univerzitet Crne Gore-Pomorski fakultet, Podgorica-Kotor.

Čulić, Gracijela (1999-2001). Mikrotoponimi Boke kotorske u arhivskim dokumentima, Godišnjak Pomorskoga muzeja u Kotoru 47-49, 111-119.

Čulić, Gracijela (2002). Mikrotoponimi u arhivskim dokumentima, Godišnjak Pomorskoga muzeja u Kotoru 50, 231-246.

Frančić, Anđela; Mihaljević, Milica (1997-98). Antonimija u hrvatskoj ojkonimiji, Rasprave Instituta za hrvatski jezik i jezikoslovlje 23/24, 77-102.

Grković, Milica (1977). Rečnik ličnih imena kod Srba, Vuk Karadžić, Beograd.

Ilčev, Stefan (2012). Rečnik na ličnite i familite imena u B̋lgarite, Izdavatelstvo »Iztok-Zapad«, Sofija.

Jireček, Konstantin (1962). Romani u gradovima Dalmacije tokom srednjeg veka. Zbornik Konstantina firečeka 2, Naučno delo, Beograd.

Krivokapić, Miloš; Knežević, Saša (2017). Prilog proučavanju porijekla stanovništva i antroponimije Orahovac (Boka kotorska), Anali Zavoda za povijesne znanosti HAZU u Dubrovniku 55/1, 269297.

Lalošević, llija (2016). Utvrđeni gradovi Boke kotorske iz mletačkog razdoblja, Radovi Zavoda za povijesne znanosti HAZU u Zadru 58, 115-146.

Lončar, Milenko (2002). Filološka analiza Porfirogenetovih vijesti o Hrvatima, Filozofski fakultet u Zadru Sveučilišta u Splitu, Zadar. (doktorski rad)

Luković, Niko (1937). Prčanj - historijsko-estetski prikaz, Bokeška štamparija, Kotor.

Magaš, Damir (2002). Natural-geographic characteristics of the Boka kotorska area as the basis of development, Geoadria 7/1, 51-81.

Marasović-Alujević, Marina; Lozić Knezović, Katarina (2011). Obalni toponimi otoka Šolte, Časopis za hrvatske studije 7, 389-443.

Marković, Savo (2006). Studia Antibarensia, Gospa od Škrpjela, Perast.

Podaci na nivou naselja: Stanovnistvo prema nacionalnoj odnosno etničkoj pripadnosti po naseljima (Tabela N1) (2011). Uprava za statistiku Crne Gore. https://www.monstat.org/cg/page. php?id=536\&pageid=148 (pristupljeno 1 . V. 2019) 
Podaci na nivou naselja: Stanovništvo prema vjeroispovijesti po naseljima (Tabela N3) (2011). Uprava za statistiku Crne Gore. https://www.monstat.org/cg/page.php?id=536\&pageid=148 (pristupljeno 2. V. 2019)

Pujić, Savo (2003). Iz trebinjske toponimije: Porijeklo toponima, Tribunia 10, 131-186.

Putanec, Valentin (1963). Refleksi starodalmatskog pridjeva sanctus u onomastici obalne Hrvatske, Slovo 13, 137-176.

Radulović Lipovac, Vesna (1981). Romanizmi u Crnoj Gori, jugoistočni dio Boke kotorske, MBM-plas, Novi Sad.

RSKNJ = Rečnik srpskohrvatskog književnog i narodnog govora, I - XIX (1959-2014), Beograd: Institut za srpskohrvatski jezik.

ERHSJ = Skok, Petar (1971-74). Etimologijski rječnik hrvatskoga ili srpskog jezika, I - IV. JAZU, Zagreb.

Skok, Petar (1950). Slavenstvo i romanstvo na jadranskim otocima, Jadranski institut JAZU, Zagreb.

Skok, Petar (1927). Kako bizantski pisci pišu lična i mjesna slovenska imena, Starohrvatska prosvjeta 1-2 (nova serija I), 60-76.

Stanić, Cjelimir (1978). Toponimi Škaljara i Mula, Godišnjak Pomorskoga muzeja u Kotoru 26, 131-143.

Stanić, Cjelimir (1979-80). Toponimi Prčanja, Godišnjak Pomorskoga muzeja u Kotoru 27-28, 157-169.

Stjepčević, Ivo (1926). Vođa po Kotoru, Bokeška štamparija, Kotor.

Šimunović, Petar (1984-1985). Prvotna simbioza Romana i Hrvata. Rasprave Zavoda za jezik 10-11. $147-200$.

Šimunović, Petar (1996). Sakralni toponimi sa sut- + svetačko ime u razdoblju kasne antike do predromanike, Folia onomastica Croatica 5, 39-62.

Šimunović, Petar (2004). Bračka toponimija, Golden maketing - Tehnička knjiga, Zagreb.

Šimunović, Petar (2005). Toponimija hrvatskoga jadranskog prostora, Golden maketing - Tehnička knjiga, Zagreb.

Šimunović, Petar (2006). Hrvatska prezimena. Golden maketing - Tehnička knjiga, Zagreb.

Škaljić, Abdulah (1966). Turcizmi u srpskohrvatskom jeziku, Svjetlost, Sarajevo.

Tomić, Antun (1977). Toponimi Dobrote, Godišnjak Pomorskoga muzeja u Kotoru 25, 137-149.

Tomić, Antun (2010). Dobrota - povijenica bokeljskog pomorstva: pomorska i kulturna povijest Dobrote XVI. - XX. st., Hrvatsko građansko društvo Crne Gore, Kotor.

Vidović, Domagoj (2014a). Toponimija župe Stjepan Krst. U: Župa Stjepan Krst (1974. - 2014.). Pr. Marić, Marinko. Muzej i galerija Neum - Matica hrvatska Stolac - HKD Napredak Dubrovnik: Neum - Stolac - Dubrovnik, 133-160.

Vidović, Domagoj (2014b). Zažapska onomastika, Institut za hrvatski jezik i jezikoslovlje, Zagreb.

Vinja = Vinja, Vojmir (1998-2004). Fadranske etimologije: Fadranske dopune Skokovu etimologijskom rječniku, I - III, HAZU-Školska knjiga, Zagreb. 


\title{
AN OVERIEW OF THE TOPONYMY OF THE BAY OF KOTOR
}

\author{
Domagoj Vidović \\ Institute of Croatian Language and Linguistics, Zagreb \\ dvidovic@ihjj.hr
}

\begin{abstract}
The paper deals with around 500 toponyms in the Bay of Kotor. In the introdoctury part of the paper, basic historic and demographic data are given. In the main part, the toponyms are categorised according to motivation and etymology. The Bay of Kotor has an above-average share of toponyms derived from personal names as well as toponyms motivated by church titularies. In this category, the toponym Sutorman (sanctus Romanus) stands out as a relict of the old Romanic and Slavic symbiosis.
\end{abstract}

Keywords: toponyms; demography; Kotor; Romanic peoples; Slavs; Croats

(c) (i) Članci su dostupni pod licencijom Creative Commons: Imenovanje-Nekomercijalno (https:// creativecommons.org/licenses/by-nc/4.0/). Sadržaj smijete umnožavati, distribuirati, priopćavati javnosti i prerađivati ga, uz obvezno navođenje autorstva, te ga koristiti samo u nekomercijalne svrhe. 